\title{
PARA UMA DIDÁTICA DA IMPLICAÇÃO EM LEITURA DE TEXTOS LITERÁRIOS: A FUNÇÃO DAS MARCAS DA SUBJETIVIDADE DO LEITOR
}

\author{
POUR UNE DIDACTIQUE DE L'IMPLICATION EN LECTURE DE TEXTES \\ LITTÉRAIRES : LA FONCTION DES MARQUEURS DE SUBJECTIVITÉ DU \\ LECTEUR
}

\section{Rosiane Maria Soares da Silva Xypas ${ }^{1}$}

Resumo: Contrariamente ao ensino tradicional de literatura que consiste em apresentar a história da literatura e resumos de obras literárias, uma nova corrente de pesquisa trabalha sobre uma didática da implicação do sujeito leitor (ROUXEL e LANGLADE, 2004). Mas como identificar essa implicação? Para responder a essa questão, nós nos valemos da subjetividade do leitor, tal como definida por Langlade. Esse artigo apresenta uma experiência de ensino com estudantes do PROFLETRAS-UFPE que consiste em promover uma didática da implicação do sujeito leitor na atividade de releitura da obra Como um romance, de Daniel Pennac (1993).

Palavras-chave: didática da implicação na leitura; leitura subjetiva; marcas de subjetividade; releitura; texto literário.

Résumé : Contrairement à l'enseignement traditionnel de la littérature qui consiste à présenter l'histoire de la littérature et de résumés des œuvres littéraires, un nouveau courant de recherche travaille sur une didactique de l'implication du sujet lecteur (ROUXEL e LANGLADE, 2004). Mais comment identifier cette implication ? Pour répondre à cette question, nous nous servirons des marqueurs de subjectivité du lecteur, tels définis par Langlade. Cet article présente une expérience d'enseignement avec des étudiants du PROFLETRAS-UFPE qui consiste à promouvoir une didactique de l'implication du sujet lecteur dans l'activité de relecture de l'œuvre Comme un roman de Daniel Pennac (1993).

Mots-clés : didactique de l'implication en lecture ; lecture subjective ; marqueurs de subjectivité ; relecture ; texte littéraire.

\section{Introdução}

Contrariamente ao ensino tradicional da Literatura onde se contenta em apresentar a história da literatura e/ou resumos de obras literárias, uma nova corrente de pesquisa se volta

\footnotetext{
${ }^{1}$ É mestre em Teoria Literária pela UFPE e em Didática do Francês Língua Estrangeira pela Université Catholique de IQuest. Possui doutorado pela Université de Nantes e é docente do ProfLetras da UFPE, ocupando a função de coordenadora. É membro da CLEFS - AMSUD e integra o Centre d'Études de Langues et Littératures Anciennes et Modernes - CELLAM em Rennes 2. E-mail: rosiane.xypas@ gmail.com
} 
sobre uma didática da implicação do leitor tendo como finalidade de lhe fazer sentir as emoções e de poder exprimi-las na leitura de textos literários.

A leitura de textos literários pode facilmente se tornar puro pretexto na escola, se o professor se contentar apenas em utilizar qualquer gênero literário visando ao ensino da língua. Ora, o estudo da poesia, da prosa ou do teatro demanda notadamente atenção às teorias da estética da recepção existentes desde os anos 70 do século passado. Essa teoria volta sua atenção às reações do leitor nas leituras de textos literários.

Mesmo que a crise da Literatura tenha despontado de forma ostensiva no mundo Ocidental, os amantes da Literatura têm se inquietado com o futuro desta em suas pesquisas. Entretanto, isso parece não bastar. É necessário que a Literatura na escola seja contemplada com um agir professoral que viabilize seu ensino, por pelo menos dois motivos: o primeiro, é que não pode mais haver Literatura sem leitura de textos literários; e o segundo, é que leitura se ensina. Sendo assim, me volto para compreender a implicação do leitor literário na ação do ler, mensurando-a. Para tal, faz-se necessário compreender qual é o papel que acordamos ao leitor na Literatura.

Em ensaio bastante aprofundado, Vieira (2015) fala sobre o que é e o que não é Literatura. E eu ressalto a passagem em que este autor afirma que é o leitor que aceita a intencionalidade do texto, é ele que irá se relacionar com o texto porque o considera como parte do jogo instituído pela verdade textual, o acontecível. Dito em outras palavras, mesmo que a Obra de arte releve da intencionalidade do autor, o leitor precisa lançar mão do jogo que suscita o texto literário para promover a recepção da Obra fazendo um pacto com o texto, e eu acrescento, ampliando-o de volta a si. Esta abordagem só é permitida porque trabalhamos com as teorias da leitura subjetiva que "é um modo de leitura [que] favorece também outra questão, a da atividade de leitura do texto literário não apenas como uma fuga, uma evasão da realidade, mas também como um encontro revivido pela memória de quem lê" (XYPAS, 2017, p. 06).

Mas, trabalhar com que leitor no ensino da leitura do texto literário? Não falo de leitores ideais nem leitores implícitos, estes leitores me sugerindo mais um afastamento do que uma possibilidade de tratar intimamente a relação leitor-texto literário. Picard (1996) fala de leitor real, que é aquele que segura em suas mãos o livro e que apressado pelo tempo, mal tem tempo para ler. E não é só isso. O leitor real é aquele que tenta apreender o texto com suas faculdades de cognição e de metacognição, de razão e de emoção. É também considerado leitor real aquele que não tem medo de dizer: "Foi assim que senti" e explicitar o que a obra literária nele suscitou. 
Isso é demonstrar consciência do que se sente, do que se sabe ou se ignora da obra lida. Ora, ter consciência do que se sente e do que se sabe é poder explicitar esses saberes e sentimentos. Dá-se assim o advento do sujeito leitor no ensino da Literatura. Logo, entre os possíveis leitores, opto, no plano didático, ver meu aluno como um leitor real porque este poderá, além de inteligentemente preencher os vazios deixados no texto, criar seu próprio texto de leitor pelas marcas de sua subjetividade que nele é deixado porque nem tudo foi programado pelo texto.

Rouxel (2013) reflete sobre o que acontece com o leitor real se tudo estiver programado pelo texto. Ela pergunta qual o espaço de liberdade gozaria o leitor real? Conforme Rouxel (2013) o gesto de ler não deve desaparecer sob o ato de aprender. Enfim, a atividade de leitura não deve ser programada para o fracasso na escola cujas "as vítimas são o texto e o leitor". (ROUXEL, 2013, p. 192). E o resultado desse fracasso é que o texto literário fica sendo visto como o indesejável e o leitor como um incapaz.

Em busca de uma teoria que norteasse minha prática no ensino da leitura do texto literário com este leitor real, vi a necessidade de refletir junto a uma teoria de implicação do sujeito leitor que contemplasse a construção de sua consciência como afirma Husserl apud Bordini (2015, p. 185), pois Husserl "recusa a hipótese de que o conhecimento venha de fora da consciência”. Assim, a leitura é, em meu entender uma atividade que demanda tomada de consciência, ela pode ser ensinada e não apenas controlada. Ela não é aleatória e tem princípio, meio e fim; é um processo com diversas variantes que permeia a análise dos resultados desta ação. Assim, entender um texto é enviar para a própria consciência o que se entendeu ressignificando-o, mesmo que o leitor de texto literário seja considerado um fenômeno extratextual, como diz Compagnon (2004), ele é de fato o motor da atividade de leitura.

Trabalhando com a noção de leitor real, vejo na sala de aula, o leitor pleno de uma história particular dentro de um universo social que será despertado pelo texto literário. Ele tomará consciência do que faz nele o texto literário. O sujeito leitor é um ser subjetivo e capaz de compreender sua própria subjetividade no ato de ler. Se o leitor de texto literário compreende sua subjetividade, os sentidos do texto que ele constrói terão mais sentidos para ele porque poderá melhor ressignificar para si o que ele leu, transformando-o.

Postulamos na tomada de consciência na atividade de leitura pela explicitação das emoções sentidas na leitura de textos literários. Ela chega a seu ápice tendo a reapropriação da Obra pelo leitor, construindo o texto de leitor. 
Então, como desenvolver na escola, na formação de leitores de textos literários a explicitação da subjetividade desses sujeitos?

\section{A subjetividade perceptível analisável e a não analisável: nascimento de um alterleitor}

Buscando compreender como didatizar a subjetividade na leitura de texto literário do sujeito leitor e como analisá-la, parto do princípio que a subjetividade se manifesta de no mínimo dois modos: uma é perceptível-analisável e a outra, perceptível não-analisável.

A manifestação da subjetividade de leitura perceptível não-analisável é aquela que sempre escapará do próprio leitor que a vivencia, as sensações, emoções que seguem o sujeito leitor no ato da leitura. A subjetividade perceptível não-analisável se resguarda no foro íntimo, no aconchego da mais profunda intimidade de quem lê. A subjetividade que escapará sempre ao sujeito-leitor advém de suas primeiras emoções, do desvendar de um contato adâmico desbravado pela leitura. Ele, o leitor, é impotente face às emoções que sente diante do que lê porque não consegue nomeá-las. Ele perde e se perde nos recônditos mais sombrios e íntimos do seu eu. Ela ocorre geralmente no nível primeiro da leitura, de uma leitura fluída e corrente. Desta leitura o sujeito leitor guarda algo que desconhece, mas (quase) sempre desabrocha quando lê um texto que lhe emociona.

Mas um saber consciente da dimensão afetiva na leitura pode ser muito eficaz no plano do ensino em sala de aula. A esta dimensão dou o nome de subjetividade perceptível analisável.

A subjetividade perceptível analisável é aquela que advém, por exemplo, da releitura de um trecho da obra ampliando a demanda de explicitação das emoções do leitor. É na releitura de um trecho que o sujeito leitor toma consciência do que suscitou nele a Obra. Uma dimensão clara da percepção analisável na obra são as marcas de subjetividade do sujeito leitor. Onde e como podem ser encontradas? Nos gestos de leitura. Quais são eles? Quando ele anota nas margens do livro, por exemplo, uma passagem que mais gostou na obra, ou quando sublinha o que não entendeu, quando faz orelhas no livro para não esquecer a página do trecho que leu e o tocou, entre outros gestos de ler. Você já parou para se observar lendo? Saberia dizer quais são seus gestos de ler? Por isso, esta segunda forma, ou seja, a perceptível analisável, ao contrário da primeira, pode ser subjugada à consciência do leitor porque esta vai dar norte aos sentimentos suscitados pelo sujeito leitor do texto literário lido. Assim, a leitura ativa os níveis cognitivos e afetivos do sujeito-leitor, marcando-o. Enfim, é graças à subjetividade analisável 
que ler textos literários nesta perspectiva faz do sujeito leitor um ator social consciente de seus sentimentos, de sua dimensão afetiva na relação ao lido.

Se no agir professoral, a subjetividade pode ser exteriorizada, privilegio a descrição como modo de escrita capital para o ensino de uma leitura ousada a partir de si, como afirma Rouxel (2018) porque o texto literário mexe com o sujeito leitor em várias dimensões: psicológicas, sociais, emocionais, cognitivas, entre outras.

A leitura literária se faz mais envolvente quando compreendemos que os vazios do texto, por exemplo, uma vez preenchidos, podem dar ao leitor condições também de explicitá-los. Em uma só frase: ele poderá nomear seus sentimentos, suas emoções sentidas com o texto lido. Mas esta atitude ou postura no tocante à leitura literária envolvendo análises dos processos subjetivos dos alunos só pode ser efetivada se o sujeito leitor tomar consciência do seu saber sobre o que sente ${ }^{2}$. Para despertar tal atitude no aluno, para lhe ajudar na tomada da consciência do ler a partir de si, o agir professoral é essencial.

Compreendemos que as emoções agem como um guia que direciona a construção de sentidos do sujeito leitor. Ela é segundo Goodman (1955) apud Jouve (2010, p. 123) “um índice que nos permite compreender como a obra significa". Ora, de quê compreensão se trata? Pensamos na compreensão explícita da subjetividade do leitor. Segundo Dantzer (2004, p. 04) "é constatado há muito tempo que as emoções influenciam nossa memória, orientam nossa atenção e são essenciais na comunicação". Se as emoções guiam o leitor para um equilíbrio durante o processo da leitura, por que não levá-las em consideração na didática da leitura literária, sobretudo com alunos facilmente inseguros tanto pelos fatos linguísticos quanto culturais $?^{3}$

\footnotetext{
${ }^{2}$ Sobre a necessidade e a aplicabilidade da tomada de consciência na aprendizagem ver nosso artigo: Le rapport à la langue française de Nancy Huston dans Lettres Parisiennes - Histoire d'éxil: Pour l'écriture d'une biographie langagière (A relação com a língua francesa de Nancy Huston em Cartas Parisienses - História de Exilio: Pela escrita de uma biografia linguística em Francês Língua Estrangeira na Revista Lettres Françaises, vol. 22017.

${ }^{3}$ L'émotion est donc selon Goodman (1955 apud JOUVE, 2010, p.123) « un indice qui nous permet de comprendre comment l'œuvre signifie ». Or, de quelle compréhension s'agit-il ? Nous pensons à la compréhension explicite de la subjectivité du lecteur. Selon Dantzer $(2004$, p. 6) «il est prouvé depuis longtemps que les émotions influencent notre mémoire, qu'elles orientent notre attention, qu'elles sont essentielles dans la communication ». Si les émotions guident le lecteur pour un équilibre durant le processus de la lecture, pourquoi ne les pas prendre en considération dans une didactique de la lecture littéraire, notamment avec les étudiants sont facilement insécurisés, aussi bien par des faits linguistiques que par des faits culturels ? In - XYPAS, Rosiane. Le rapport à la langue française de Brina Svit dans Moreno (2003) et Petit éloge de la rupture (2009). Diálogo das Letras, Pau dos Ferros, v. 7, n. 1, p. 4-20, jan./abril. 2018. (Tradução nossa)
} 
Então, quando o leitor preenche o vazio deixado pela Obra, o que ele vê? Como lê? Sente uma aproximação de si próprio, de reconhecimento, de sentimentos incitados pela ousadia de se fazer uma leitura a partir de si, da qual fala Rouxel (2018)?

$\mathrm{Na}$ atividade leitora, o leitor faz o movimento do sair e voltar para dentro de si repetida vezes. Por isso, sair de si e voltar para si pode favorecer um encontro consigo mesmo pelo Outro e talvez ampliar sua dimensão humana. É o pacto do leitor com ele mesmo e não apenas com o texto que pode contribuir para a percepção dos efeitos da leitura em si, criando o texto de leitor.

A criação do texto do leitor é um tipo de co-elaboração do texto lido agora feito seu. Nasce o que chamo de alterleitor. Eu disse em um artigo meu, que considero a atividade de leitura literária como atividade que abriga emoções diversas do leitor literário. Hoje, acrescento que ela é uma atividade que desencadeia diversas emoções no sujeito leitor que devem ser colhidas. E é nesse desencadeamento que se constrói um sujeito ativo na construção de sentidos graças a uma atividade leitora que vê o sujeito ativo como um:

[...] alterleitor (...) ser em elaboração, em processo. (...) que pode ser constituído e só pode existir a partir da tríade dinâmica leitor-obra-leitura em que se busca compreender o que resulta dos processos do investimento do imaginário daquele que lê. Construindo-se em um outro diferente. (XYPAS, 2018, p. 192).

\section{O leitor, o texto literário e sua reapropriação da obra lida: por uma metodologia do ensino da leitura literária}

Todo leitor se lê nas obras que lê. Todo ele se reinventa quando lê o mundo inventado pelo autor. Assim, a reapropriação da Obra pelo leitor pode acontecer de várias formas. Tomo aqui a palavra reapropiação como sinônimo explícito de modificação da Obra pelo leitor, e deste, pela Obra. Só daí nascerá o texto do leitor, o acontecível como objeto observável e analisável para o ensino.

Penso que o que o leitor tenha a dizer seja possível pelos estudos literários notadamente porque estes "dedicam um lugar muito variável ao leitor" (COMPAGNON, 2001, p. 139). Este lugar, muito variável por sinal, é longe de ser negativo na voz de Compagnon (2001). Particularmente, o compreendo como um trunfo no qual todo aquele que trabalha com o texto literário poderá experimentar consigo mesmo, em geral, e na sala de aula, em particular.

Compagnon (2001) motiva o pesquisador a rever as posições teóricas e práticas existentes no tocante ao tratamento dado ao leitor literário. Ele afirma o que segue: "de um lado, as abordagens que ignoram tudo do leitor, e do outro, as que o valorizam, identificam a literatura 
à sua leitura". (op. cit., 2001, p. 139). Por uma questão metodológica, optamos aprofundar a leitura de textos literários viabilizando a voz do sujeito leitor. Pois, se o sujeito leitor não é levado em conta em sua formação de prazer na leitura literária, que tamanha lacuna, afinal, poderá ser fomentada no espírito do mesmo? Além disso, é colocando o leitor literário no coração da recepção da obra que se instituirá o que Compagnon chamou de "um discurso subjetivo" (op. cit., 2001, p. 164). É esse discurso subjetivo livrado pelos alunos leitores que me interessa. E com a leitura subjetiva no ensino de Literatura, o discurso subjetivo poderá ser analisado.

Na escola, há possibilidades de escolha de textos literários pelos professores para os alunos. Pergunto: Em que se baseia o professor quando ele escolhe as obras para serem lidas por seus alunos? Respondo: Primeiramente, em sua experiência de leitor literário. Em segundo lugar, no público que tem diante de si. Em terceiro lugar, no que deseja fazer com o texto que for escolhido.

A experiência do aluno-professor de Mestrado Profissional em Letras é na maioria das vezes pautada nas leituras de textos informativos. Das turmas do PROFLETRAS pelas quais passei, destaco que $25 \%$ dos alunos dizem se sentir à vontade, às vezes, com o texto literário. Outros dizem se sentir totalmente à vontade, apesar de não saberem muito bem como trabalhálos. Outros não. Não se sentem à vontade com gêneros literários. Mas na hora de se elaborar atividades com o texto literário é a experiência enquanto sujeito leitor que predomina, sobretudo nos textos (im)postos pelo Programa.

Essas respostas dos alunos me fizeram refletir. Propus um trabalho no Profletras turmas 3 (2016) e 4 (2017) com uma obra completa. Tendo em vista fazê-los degustar suas próprias leituras que chamo de apropriação do texto, elaborei atividades com um capítulo da obra, ou seja, um excerto. E que vantagens teríamos com um trabalho de leitura literária com fragmentos? Rouxel (2013, p. 173) afirma que "essa atividade de recorte é verdadeiramente uma das mais significativas entre os procedimentos de apropriação do texto lido". Pode dizer também que longe está nossa memória de poder selecionar toda a obra lida a ponto de guardála. Toda apropriação se dá com a escolha (in)consciente de algumas partes da obra porque há ressignificação para o leitor. Às vezes, ele desconhece, mas às vezes ele sabe exatamente porque escolheu aquela parte da obra. Mas quem de nós se pergunta porque o destaque dado a essa ou aquela frase, a esse ou aquele parágrafo de um texto quando o lemos? 
Quando escolhi trabalhar com a obra Como um romance (1993) de Daniel Pennac pensei em mergulhá-los em seu próprio universo pelo viés da cultura francesa. Pensei em seguida em atividades que destacassem as reações dos alunos-professores. Ora, a obra escolhida, fala do universo real, a saber, a leitura na escola, em casa, na sociedade, no mundo. Além disso, o personagem principal é um aluno, a situação é a escolar, a familiar, breve, um universo real encontrando o universo de ficção que comungaria no desvendar dos espelhos fantasmáticos dos sujeitos leitores. Dizendo isso, não me fecho às escolhas de obras distantes do universo real e de ficção do professor ou do aluno.

O desafio maior é, a meu ver, como fazer dentro da sala de aula com a obra completa ou parte dela. Por isso, tendo meu objetivo em explicitar as marcas da subjetividade de meus sujeitos-leitores do PROFLETRAS escolhi um capítulo da obra como já mencionado, e pude analisar pelos seus escritos, o que estava em suas memórias, estas que já fazem um recorte do recorte do texto, que condensa ainda mais as significações ricas e variáveis de cada sujeito leitor. Foi minha meta: a busca de compreender como a obra lhes tocou a ponto de poder objetivá-las, falar delas, escrever sobre elas, ressignificá-las, apropriarem-se delas, enfim criar seus textos de leitores singulares e diversos ao mesmo tempo. É na atividade de releitura que se encontra um melhor espaço psicológico consciente para a implicação do sujeito leitor.

\section{Apresentação da narrativa Como um romance (1993) de Daniel Pennac e a implicação da atividade de Releitura do excerto escolhido}

Antes de falar do capítulo escolhido e apresentar a atividade de releitura que propus para a análise da subjetividade dos alunos-professores, falarei da Obra que me inspirou na criação desta metodologia de ensino de leitura de texto literário.

A obra Como um romance, do autor francês Daniel Pennac (1944-), está dividida em 57 capítulos e quatro partes e trata do tema da leitura, dos deveres e direitos do leitor. É a história de um garoto que, como vários na sociedade, convivem no dia-a-dia da escola com a leitura obrigatória. O livro que o personagem da narração tem que ler, e em pouco tempo, é bem grosso, o que o aflige deveras. Os pais do personagem central agem como a maioria dos pais na sociedade de hoje, ou seja, impondo-lhes o dever da escola e não sabem bem como lidar com a situação quando o filho não quer ler. Geralmente, não sabem, porque a atividade é imposta. Difícil lidar com a imposição, não é? Mas o filho precisa ler porque vale nota! 
Dessa situação no romance, nascem diversas formas de poder descortinar para o sujeitoleitor suas vivências com a leitura. Diversas situações, relativas a cada um de nós enquanto leitor são apresentadas na narração e à medida que a leitura avança, o leitor pode se identificar com um tipo ou outro de situação vivida, com um tipo ou outro de leitor que surge na Obra, e quem sabe projetar-se e ser modificado com a Obra...

Vale ressaltar que, antes de dizer aos alunos do Profletras o que eu queria com a leitura da obra escolhida, eles leram integralmente a Obra, à vontade. Eu lhes dei dois enunciados:

1. O que lhes evoca este título? Na sala de aula, levantaram hipóteses do que poderia se tratar o livro. E eu as anotei.

\section{Leiam este livro.}

Nenhuma das hipóteses de nossos alunos do PROFLETRAS foi confirmada. Pensaram que o Como um romance seria um livro teórico de como aprender a ler. O contexto acadêmico influenciando nessas? Não sei responder esta questão. Sei que o trabalho com hipóteses na leitura de texto literário assume "uma forma de caráter provisório, como ponto de partida e como possibilidade de formar teorias", segundo Barros $(2017$, p. 6). Além disso, vejo que elas favorecem o sujeito leitor em no mínimo três dimensões:

i) aguça-se a curiosidade sobre o que virá a seguir no texto; ii) exige-se dele criatividade; iii) implica- o no processo de leitura.

É bem certo que as hipóteses possam ser elaboradas graças ao texto literário. Graças a elas, pode-se provar a cumplicidade entre o texto e o leitor; provocar inseguranças momentâneas logo desvendadas com a continuidade da leitura e ajudar a construir os sentidos do texto de forma cognitiva e afetiva. Enfim, o sujeito leitor que lê elaborando hipóteses desenvolve melhor sua dinâmica na atividade leitora.

Quanto ao enunciado 2, eles leram o livro em casa, no ônibus, onde quiseram e como puderam demonstrando a face do leitor real deste início do século XXI. A meu ver, esta didática da atividade de leitura à vontade, fora dos muros da escola, sem demanda de obrigação para responder questões pouco importa se sejam abertas ou fechadas, atividades objetivas ou subjetivas no primeiro contato com a Obra, é uma excelente tarefa para lhes dar autonomia do que há de vir, para lhes fazer sentir melhor a obra. No dia combinado, trouxeram o livro para a sala de aula.

Escolhi o capítulo 56 para a atividade de leitura porque, em seu conteúdo, ele apresenta duas situações extremas com o ato de ler. A primeira delas é que uma jovem em um carro em 
alta velocidade joga pela janela um livro grosso. A outra situação fala sobre alguém que, na prisão, fumou literalmente Platão e rasgou a Bíblia ou um outro livro para se limpar depois de ter ido ao banheiro.

Ora, diante destas situações instigantes em relação ao livro, o que fazer o professor mediador da leitura do texto literário para estimular a consciência do leitor sobre o capítulo lido? Entendo por professor mediador aquele que tem uma escuta atenta às falas e/ou à escrita dos alunos quando lidam com o texto literário. A mediação é uma ponte entre o livro e o ser que lê. Depois da leitura prazer viabilizada sem tarefas imediatas para serem feitas, o aluno, a meu ver, estará mais aberto para trocar suas impressões sobre o lido com seus pares ou seu professor. Ele pode até se recusar de expor suas impressões, ele pode preferir escrever suas impressões apenas e não compartilhá-las. É um direito que não deve ser retirado.

Agora, apresentamos as escritas compartilhadas entre os alunos-professores do Profletras na atividade de leitura.

Pontuo que é só na releitura de algumas passagens da Obra que se dará a exploração didática que elaborei, objetivando as marcas de subjetividade de leitura na construção do texto do leitor.

\section{Marcas da subjetividade do leitor: por uma didática da implicação na leitura do texto literário}

É de um artigo de Gérard Langlade (2013) que me inspiro tanto para analisar as marcas da subjetividade na leitura de textos de ficção feita pelos alunos-professores do PROFLETRAS - UFPE quanto seu interesse didático. A escola deve não temer a explicitação bem fundamentada, bem acompanhada pelo mediador de leitura de textos de ficção no tocante às reações pessoais dos alunos sejam elas quais forem.

Ora, quantos de nós, na escolha de uma obra ou de um trecho para se trabalhar na sala de aula, não sentimos que fazemos a escolha, pela nossa emoção? Muitas vezes por associações de ideias ou mesmo espontaneamente, este ato cheio de cognição e emoção? Enfim, o que nos leva a escolher uma obra ou um trecho da mesma, uma poesia e não outra, um conto e não uma crônica ou vice-versa, senão nosso desejo de trabalhar na sala de aula com aquele texto eleito por nós? Vou considerar que acertamos sempre em nossas escolhas. Se os alunos não gostam, isso é outra história. As marcas de suas subjetividades sempre se manifestam. A pergunta é a 
seguinte: O que a escola faz com esse não gostar? Respondo: ela cria representações sociais e os que a fazem, compartilha a doxa de que aluno não gosta de ler!

No entanto, a minha questão aqui, é a atividade de leitura na busca da compreensão das marcas de subjetividade do sujeito leitor. Langlade (2013) vai chamar essas marcas de subjetividades que afetam a todos os leitores de "ecos íntimos" (LANGLADE, 2013, p.25). São esses ecos íntimos de leitor que me interessam atualmente nos estudos literários. Defino assim os ecos íntimos de leitor em seus detalhes minúsculos, a saber, quando o aluno oraliza ou descreve, como dirá Langlade (2013) - "um odor, uma cor, uma imagem, um ruído, uma emoção" (LANGLADE, 2013, p. 26). Os ecos íntimos são manifestos de lembranças, de uma vibração, de uma emoção que às vezes o sujeito leitor não consegue nomear.

Ora, essas marcas de subjetividades presentes e diria até inerentes ao ato de leitura precisa neste século ser estudado com afinco pensando o professor em propostas para a formação do sujeito leitor. Ainda com Langlade (2013) e tenho constatado que os ecos íntimos do leitor literário são como um encontro: “(...) onde o universo da ficção, a banal realidade do mundo e o velado espelho dos fantasmas se confundem" (LANGLADE, 2013, p. 26). Esta citação é legítima para meu propor enquanto mediadora de leitura na sala de aula, é igualmente legítima quando analiso os meus e os gostos de meus alunos despertados pela leitura de textos literários.

O encontro do universo real com o universo de ficção pode abrir os sentidos do sujeito leitor, pois esses universos entram em choque com a banalidade vivida pelo leitor no mundo e esses momentos podem fazer emergir o lado mais profundo do ser, agora desembaçado de seu próprio espelho fantasmático. O que fazer com a teoria da irrupção da subjetividade na atividade leitora, no tocante à aplicação na sala de aula? Respondo que as reações que demonstram as marcas da subjetividade do sujeito leitor são, portanto observáveis. Como afirma Langlade: “as reações aparecem na consciência do leitor no decorrer da leitura". Logo "não são um ponto cego da leitura”. (LANGLADE, 2013, p. 27).

Mas onde recolher essas marcas da subjetividade? Quando elas se fixam ou se manifestam no texto? Por exemplo, logo que no texto o autor não descreve física e psicologicamente uma personagem, como é o caso de uma parte do texto de Daniel Pennac com o qual eu trabalhei. A situação desencadeadora das marcas da subjetividade dos alunosprofessores foi a seguinte: havia uma personagem que lia um livro e o jogou pela janela em um carro em alta velocidade. É tudo que é livrado ao leitor no excerto do romance trabalhado. 
Na primeira tarefa, pedi para que cada aluno-professor descrevesse a leitora do romance para mim. O objetivo era que eles explicitassem por escrito suas leitoras do romance lido porque me interessava saber quem eram elas e como eram elas. Pedi igualmente que descrevessem por escrito, o livro e o carro da leitora deles, a fim de que pudessem liberar seus ecos íntimos de sujeito leitor.

As respostas foram muito peculiares, advindas do foro íntimo de cada sujeito-leitor. A materialização por escrito dada àquela leitora que jogara o livro pela janela em um carro em alta velocidade passa a fazer parte da consciência do sujeito leitor em sua construção de sentidos. Cada um teve que tomar consciência de como era física e psicologicamente a personagem leitora. E ao mesmo tempo ele se reconhece igualmente como sujeito-leitor. Essas marcas de subjetividade se manifestam, porque ele, o sujeito leitor nomeia a leitora dele, o livro que ele imaginou, o carro que the foi evocado ao ler o texto literário.

Ora, nomear, ajuda a criar sentidos, fixar significados para aquele que o faz, preenche os vazios deixados pelo autor do texto criando o seu texto de leitor. Essa atitude materializa a subjetividade na leitura.

Quando apliquei essa tarefa, observei como cada um mergulhou mais profundamente em seu eu, tomando consciência do ler a partir de si, já evocada mais acima. Lemos claramente nos textos escritos pelos alunos-professores uma explicitação de suas subjetividades agora observáveis em vários níveis. Chamarei esta atitude analisada pelos escritos dos alunosprofessores como superposição temporal físico e psicológico. Física porque ligada ao corpo que lê e psicológica porque ligada às reações cognitivo-afetivas - são constantes logo, observáveis - de cada um que lê. Em outras palavras, ao mesmo tempo em que o aluno-professor foi convidado a explicitar física e psicologicamente a personagem leitora, eles mesmos afirmaram que a ação do jogar o livro pela janela daquela personagem leitora, lhes tocou e disseram que ela estava infeliz e decepcionada com o que lera. Diversos motivos foram descritos para tal infelicidade. Obtive as reações gerais, a infelicidade da personagem leitora e as singulares de cada aluno-professor que demonstro logo abaixo:

- a infelicidade é dada pelo sentimento de insatisfação daquilo que lia;

- a sensibilidade em demasia da leitora, pois o livro a tocou profundamente abrindo feridas mal curadas;

- o sentimento de frustração, de revolta, problema mental, por descontentamento. 
- o horizonte de expectativa rompido cruelmente, sentimento de raiva e decepção com o lido;

- a impotência da personagem leitora de não poder controlar o destino dos personagens;

Destaco que é notável o trabalho com hipóteses voltadas para o desenvolvimento do horizonte de expectativa de cada aluno-professor sujeito leitor. O horizonte de expectativa é o estado de uma espera-ativa entre o que o leitor imagina e o que descobrirá com a leitura do texto literário. O horizonte de expectativa é o depósito de esperança, conversação íntima entre as experiências vividas latentes e o encontro com o lido. Por ele, o leitor quer e às vezes, consegue se emocionar, se ressignificar.

Vale ressaltar que a criação dos textos dos alunos fica ainda mais clara pelas ocorrências de palavras de sentimentos, tais como insatisfação, sensibilidade, feridas mal curadas, frustração, decepção e raiva. O estado emocional do leitor é explicitado pela identificação com a passagem do texto em questão. Eles escreveram ainda que a infelicidade da personagem que jogou o livro pela janela de um carro em alta velocidade advém do horizonte de expectativa rompido cruelmente; a personagem leitora tem um problema mental ou ainda ela sente revolta, descontentamento e impotência. Não estaria aí o sujeito leitor em uma superposição temporal física e psicológica do lido, desvelando seu espelho fantasmático durante a leitura do texto em questão?

Quanto ao nível físico da personagem-leitora do romance explicitada pelas descrições suscitadas por cada leitor também variam, demonstrando assim, de fato pondo à prova a meu ver, as teorias sobre a leitura de mundo que cada sujeito leitor carrega em si mesmo um mundo inteiro seja real e/ou imaginário, segundo sua experiência de vida. A personagem-leitora era:

- Ela era negra;

- era branca;

- era ruiva. E quase todas usavam acessórios.

Quanto ao livro, este era grosso certo, porque o autor do texto, Daniel Pennac diz, mas não diz a cor dele, o que evoca no imaginário dos alunos-professores um livro rosa, outro vermelho, outro ainda preto, outro azul, outro amarelo. E o carro enfim também varia de cor e modelo, pois um era vermelho, outro preto, nacional e importado.

Essas marcas das subjetividades de cada sujeito-leitor não podem ser conhecidas pelo mediador de leitura, caso ele não elabore atividades, enunciados de tarefas visando à 
explicitação do que o texto suscita ao sujeito-leitor. Além disso, o que é bem curioso é que muitas vezes essas subjetividades passam despercebidas até dos próprios sujeitos-leitores. Por isso, penso sobre a importância deste tipo de tarefa que são fundamentadas na explicitação de sentimentos-emoções do texto lido. Essa tarefa é simples e direta e pode ser aplicada na sala de aula na escola. $\mathrm{O}$ aluno poderá se sentir mais valorizado porque ele será um modificador de Obras que o modificam.

\section{Considerações Finais}

O presente texto analisou as marcas das subjetividades da Obra lida por alunosprofessores do PROFLETRAS da UFPE, Como um romance (1993), de Daniel Pennac. As atividades elaboradas com um dos capítulos da Obra foram inspiradas nas teorias da leitura subjetiva no ensino de Literatura (ROUXEL, 2013; Langlade, 2013).

O processo metodológico adotado partiu da demanda de leitura livre fora dos muros da escola. Pedi-lhes simplesmente que lessem a obra. Quando os alunos-professores trouxeram para a sala de aula o romance em questão, diversas tarefas lhes foram pedidas visando à explicitação das marcas de suas subjetividades.

Os resultados obtidos com a análise dessas marcas de subjetividades dos alunosprofessores do Mestrado Profissional me fizeram entender que se, por um lado, esses sujeitos leitores se fazem evidentemente presentes no texto lido, graças à patente implicação dos mesmos na leitura, e por implicação compreenda-se também projeção, identificação, sentimentos investidos no texto lido, por outro, o professor de Língua, tendo que lidar com o texto literário na escola, poderá - seja a leitura obrigatória ou não - buscar meios diversos para implicar o aluno no ato de ler.

Ora, penso que a formação do leitor de texto literário se dá, sobretudo, no onde e como envolvemos os alunos na atividade da leitura literária. Dos sentimentos mais variados ao conteúdo que o livro exprima cabe ao leitor, e apenas a ele, o comando para a reapropriação do texto, criando o seu texto de leitor em conjunto com uma leitura de retorno a si, de ressignificar e explicitar suas reações de sujeito-leitor.

Retomo meu pensar sobre o agir professoral. Este não deve se concentrar ou se contentar com as perguntas evasivas de Livros didáticos - sobre o que o eu lírico e o personagem faz, pensa e sente. Agindo dessa maneira, o professor-mediador contribuirá essencialmente para o desengano da formação do leitor de texto literário. Mas, se se optar por um agir professoral 
voltado para a tomada de consciência das construções de sentidos no texto literário explicitando as subjetividades do sujeito-leitor, elevaremos esta atividade na vida escolar. Porque o aluno pode aprender todos os dias a construir a vida com sentidos, na medida em que não se sente mais um mero repetidor de formas e reconhecedor de gêneros na atividade leitora. Pelo contrário, além de repetir formas e reconhecer gêneros, o aluno sabe compreender o seu próprio conhecimento porque se sente participante, logo interligado na forma e no fundo, ou seja, na estrutura e no conteúdo.

A proposta aqui teve como finalidade, convidar os professores de língua e literatura na escola a pensarem em atividades de leitura com o texto literário, implicando o sujeito-leitor no processo da construção de sentidos pela explicitação de suas próprias subjetividades, lembrando que ele deve vivenciar o prazer estético, um processo humanizador na formação leitora.

Quando o seu aluno-leitor entender que pode explicitar suas emoções e tem a oportunidade de fazê-lo, o que suscitará nele este ato de consciência? Aumentará a intimidade com a Obra que ele está ajudando também a criar, a obra que ele aceitou jogar o jogo com o seu pacto de leitor?

Enfim, é importante mudar os hábitos de análises das leituras de textos literários de nossos alunos-professores para que eles possam mudar os hábitos de análises dos alunos deles na escola. Espero que essa mudança de hábito de análises favoreça mudanças positivas e implique vivamente o sujeito leitor em sua formação literária.

\section{Referências}

BARROS, José d'Assunção. As hipóteses nas ciências humanas - Aspectos metodológicos. São Paulo: Vozes, 2017.

BORDONI, Maria da Glória. Fenomenologia e Hermenêutica: impactos sobre os estudos literários. In: Repensando a teoria literária contemporânea. (Org.) José Sedycias, Recife: Editora UFPE, 2015.

COMPAGNON, Antoine. O Leitor. In - O Demônio da teoria - Literatura e senso comum. MOURÃO Cleonice; SANTIAGO, Consuelo (Trad.) São Paulo, Humanitas, 2001, p.139-164.

LANGLADE, Gérard. O sujeito leitor, autor da singularidade da obra.(Trad.) Rita JoverFaleiros, In - ROUXEL, Annie; LANGLADE, Gérard; REZENDE, Neide Luzia, (Org), Leitura Subjetiva e ensino de literatura. São Paulo, Alameda, 2013, p. 25-38.

PENNAC, Daniel. Como um romance. (Trad.) Leny Werneck, Rio de Janeiro, Rocco, 1993.

PICARD, Michel. La lecture comme un jeu. Paris : Édition de Minuit, 1996. 
ROUXEL, Annie. O Advento dos leitores reais. (Trad.) Rita Jover-Faleiros, In- ROUXEL, Annie; LANGLADE, Gérard; REZENDE, Neide Luzia, (Org.), Leitura subjetiva no ensino da Literatura, São Paulo, Alameda, 2013, p. 191-208.

A Tensão entre utilizar e interpretar na recepção de obras literárias em sala de aula: reflexão sobre uma inversão de valores ao longo da escolaridade. (Trad.) Marcello Bulgarelli), In- Leitura subjetiva no ensino da Literatura. (Org.) ROUXEL, Annie; LANGLADE, Gérard; REZENDE, Neide Luzia. São Paulo, Alameda, 2013, p. 151-164.

. Oser lire à partir de soi. Conferência proferida na ABRALIC - 2018 na Universidade Federal de Uberlândia - UFU, traduzida oralmente sob meus cuidados em 02.08.2018.

VIEIRA, Anco Márcio T. O que é e o que não é literatura? - In - João Sedycias, (Org), Repensando a teoria literária contemporânea. Recife e Llinois: Southern llinois University Edwardsville e Universidade Federal de Pernambuco, 2015, p. 33-86.

XYPAS, Rosiane. Construction langagière héritée et décidée dans Lettres parisiennes histoire d'exil : le rapport à la langue française de Nancy Huston. Revista Lettres Françaises, Araraquara n. 181, 2017, pp.145-158. ISSN Eletrônico 2526-2955.

A Leitura literária como retorno a si: análise da recepção de Moreno (2003) de Brina Svit em Francês Língua Estrangeira (FLE). In- LENDL, Aluizio; SILVA, Cássia da; COSTA JUNIOR, José Veranildo Lopes (Org.), Ensino de Línguas e Literaturas: Questões da Contemporaneidade.Rio de Janeiro: Oficina da Leitura, 2018. 238 p. Revista de Educação, Capítulo XIII, Vol. 1, 2018, pp. 187- 201. ISBN: 978-85-66224-17-7.

A Leitura subjetiva no ensino de Literatura: O texto do leitor em L'Analphabète de Agota Kristof. Revista Eletrônica de Educação - RELEDUC, v. 1, p. 33-48, 2018. http://portal.fundacaojau.edu.br:8081/journal/index.php/revista_educacao.

Le rapport à la langue française de Brina Svit dans Moreno (2003) et Petit éloge de la rupture (2009). Diálogo das Letras, vol. 7 N. 1, 2018, pp. 04-20 ISSN: 2316-1795.

. Três vozes femininas escrevendo na língua do outro: entre tensão e sintonia. Revista ORGANON n. 63, 2017, pp. 1-17, E-ISSN: 22388915

Recebido em 20 de agosto de 2018. Aceito em 23 de outubro de 2018. 